\title{
Antibiotics from predatory bacteria
}

\author{
Juliane Korp ${ }^{1}$, María S. Vela Gurovic ${ }^{2}$ and Markus Nett ${ }^{* 1,3}$
}

\author{
Review \\ Address: \\ ${ }^{1}$ Leibniz Institute for Natural Product Research and Infection Biology - \\ Hans-Knöll-Institute, Beutenbergstr. 11, 07745 Jena, Germany, \\ ${ }^{2}$ Centro de Recursos Naturales Renovables de la Zona Semiárida \\ (CERZOS) -CONICET- Carrindanga Km 11, Bahía Blanca 8000 , \\ Argentina and ${ }^{3}$ Department of Biochemical and Chemical \\ Engineering, Technical Biology, Technical University Dortmund, \\ Emil-Figge-Strasse 66, 44227 Dortmund, Germany \\ Email: \\ Markus Nett ${ }^{*}$ - markus.nett@bci.tu-dortmund.de \\ * Corresponding author \\ Keywords: \\ antibiotics; genome mining; Herpetosiphon; myxobacteria; predation
}

\author{
Beilstein J. Org. Chem. 2016, 12, 594-607. \\ doi:10.3762/bjoc. 12.58 \\ Received: 29 January 2016 \\ Accepted: 11 March 2016 \\ Published: 30 March 2016 \\ This article is part of the Thematic Series "Natural products in synthesis \\ and biosynthesis II". \\ Guest Editor: J. S. Dickschat \\ (C) 2016 Korp et al; licensee Beilstein-Institut. \\ License and terms: see end of document.
}

\begin{abstract}
Bacteria, which prey on other microorganisms, are commonly found in the environment. While some of these organisms act as solitary hunters, others band together in large consortia before they attack their prey. Anecdotal reports suggest that bacteria practicing such a wolfpack strategy utilize antibiotics as predatory weapons. Consistent with this hypothesis, genome sequencing revealed that these micropredators possess impressive capacities for natural product biosynthesis. Here, we will present the results from recent chemical investigations of this bacterial group, compare the biosynthetic potential with that of non-predatory bacteria and discuss the link between predation and secondary metabolism.
\end{abstract}

\section{Introduction}

Microorganisms are major contributors to primary biomass production and nutrient cycling in nature. The composition of a microbial community shapes an ecosystem, but is also responsive to biotic and environmental cues. Predation is among the ecological forces, which drive the diversity and dynamics of microbial consortia [1-3]. While protozoa and nematodes are widely known as bacterivores [4,5], the existence of predatory prokaryotes is often neglected despite the abundance of the latter and their early occurrence in the history of life, likely preceding eukaryotic predators [6-9].

Predatory behavior is in fact not uncommon for bacteria. It can be observed in many different species, which are found in the actinobacteria (e.g., Agromyces ramosus) [10], the chloroflexi (e.g., Herpetosiphon spp.) [11,12], the proteobacteria (e.g., Bdellovibrio bacteriovorus, Myxococcus xanthus, Ensifer 
adhaerens, Cupriavidus necator, Lysobacter spp.) [13-17], the bacteroidetes (e.g., Saprospira grandis, Tenacibaculum spp.) $[18,19]$, and even in the cyanobacteria (e.g., Vampirovibrio chlorellavorus) [20]. Depending on their feeding behavior, that is, whether or not their diet relies exclusively on prey consumption, these bacteria have been classified as obligate or facultative predators [6]. While obligate predators can only survive by consuming other bacteria, facultative predators readily switch to a saprophytic lifestyle in the absence of appropriate preys [21]. Another division of predatory bacteria is based on their hunting strategies [22]. Epibiotic predation involves attachment to the outer surface of the prey, which is then followed by a degradation of the prey's cell wall and assimilation of cell components through specialized structures [23]. Other predatory bacteria are known to directly penetrate the prey cell in a process called diacytosis [24,25] or to selectively invade the periplasm of Gram-negative bacteria [26]. The corresponding behaviors are referred to as endobiotic and periplasmic predation, respectively [22]. Another strategy, which is called group or 'wolfpack' predation, is only practiced by facultative predators. A prerequisite for this collaborative type of hunting is a quorum of predatory cells, which pool hydrolytic enzymes, proteases or nucleases in order to lyse and feed on nearby prey [22].

Group predation occurs predominantly in bacteria, which also display social swarming behavior, gliding motility and sophisticated communication systems. Illustrative examples include the myxobacteria, as well as Lysobacter and Herpetosiphon species [6,27-29]. Members of these taxa are further characterized by their large genome sizes and their striking potential for the production of structurally diverse natural products with antimicrobial activities [12,30-35]. For many years, it has been speculated whether antibiotic biosynthesis is functionally linked to the predatory lifestyle of these organisms $[27,36]$. In this review, we will address this unresolved question both from a genomic perspective and on the basis of chemical investigations. Terrestrial myxobacteria and the genus Herpetosiphon will be in the focus of our analysis, whereas Lysobacter spp., which have just been the subject of a comparative metabolomics study [37], are not covered. For information on marine myxobacteria, readers are referred to the review article by König et al. in this Thematic Series [38].

\section{Review}

\section{Biology and biosynthetic potential of myxobacteria}

Myxobacteria are ubiquitous soil bacteria with a complex life cycle, which involves the coordinated differentiation from individual cells into multicellular fruiting bodies under starvation conditions $[39,40]$. Furthermore, myxobacteria are distin- guished by their unique gliding motility allowing a rapid swarming dispersal [41], which likely also benefits their predation strategy. Considering their highly sophisticated developmental program and their manifold social interactions, it is not surprising that fruiting myxobacteria are among the prokaryotes with the largest genomes. Their genomes typically range from 9 up to $15 \mathrm{Mbp}$ in size and contain between 7,285 (Myxococcus fulvus HW-1) and 11,599 (Sorangium cellulosum So0157-2) protein-coding sequences (Table 1) [42-47]. In comparison, the genome of the standard laboratory bacterium Escherichia coli comprises only 4.6 Mbp of DNA [48]. With a single exception, all myxobacterial genomes that have been sequenced to date consist of a single circular chromosome and feature no plasmids $[42-47,49,50]$. To evaluate the biosynthetic capabilities of the myxobacterial strains listed in Table 1, their genome sequences were scanned for the presence of putative secondary metabolite gene clusters using the publicly available online tool antiSMASH 3.0 [51]. This analysis revealed that all strains possess extraordinary capacities for natural product assembly. Interestingly, however, the number of biosynthetic loci is not linearly correlated with the genome size. The largest number of secondary metabolite gene clusters was found in Corallococcus coralloides DSM 2259 and not in the two Sorangium cellulosum strains, although the latter feature significantly larger genomes (Table 1). When the number of detected loci is related to the genome size, it becomes obvious that the Cystobacterineae strains consistently possess more biosynthesis gene clusters per Mbp of DNA than the analyzed Sorangiineae and that they also devote a larger percentage of their total nucleotides to natural product biosynthesis. Noteworthy in this context, the genera Myxococcus and Corallococcus, on the one hand, as well as the genus Sorangium, on the other, represent different nutritional types among the myxobacteria. Only the former are bacteriolytic and attack other microorganisms, whereas the latter live as cellulose degraders [36,52-54]. Although mere numbers of biosynthesis gene clusters provide no information about the identity or biological role of the associated natural products, we note that predatory myxobacteria possess a higher density of secondary metabolite gene clusters in their genomes than their non-predatory relatives.

But are these clusters indicators for predatory behavior? - To answer this question, we will take a closer look at their metabolic products using Myxococcus xanthus DK1622 as an example. This strain, a model organism for the analysis of myxobacterial fruiting body development and motility, feeds on a number of different soil bacteria upon direct contact by a mechanism called predatory rippling $[14,55]$. Although the biology of M. xanthus DK1622 had been thoroughly investigated for decades, the bacterium did not come into the focus of natural product chemists until the sequencing of its genome. Bioinfor- 
Table 1: Taxonomic assignment, nutrition, genomic and biosynthetic features of myxobacterial strains.

\begin{tabular}{|c|c|c|c|c|c|c|}
\hline & $\begin{array}{l}\text { Myxococcus } \\
\text { fulvus } \mathrm{HW}-1\end{array}$ & $\begin{array}{l}\text { Myxococcus } \\
\text { xanthus DK1622 }\end{array}$ & $\begin{array}{l}\text { Corallococcus } \\
\text { coralloides } \\
\text { DSM } 2259\end{array}$ & $\begin{array}{l}\text { Myxococcus } \\
\text { stipitatus } \\
\text { DSM } 14675\end{array}$ & $\begin{array}{l}\text { Sorangium } \\
\text { cellulosum } \\
\text { So ce56 }\end{array}$ & $\begin{array}{l}\text { Sorangium } \\
\text { cellulosum } \\
\text { So0157-2 }\end{array}$ \\
\hline Suborder & Cystobacterineae & Cystobacterineae & Cystobacterineae & Cystobacterineae & Sorangiineae & Sorangiineae \\
\hline Family & Myxococcaceae & Myxococcaceae & Myxococcaceae & Myxococcaceae & Polyangiaceae & Polyangiaceae \\
\hline Nutrition & $\begin{array}{l}\text { saprotrophic } \\
\text { predatory }\end{array}$ & $\begin{array}{l}\text { saprotrophic } \\
\text { predatory }\end{array}$ & $\begin{array}{l}\text { saprotrophic } \\
\text { predatory }\end{array}$ & $\begin{array}{l}\text { saprotrophic } \\
\text { predatory }\end{array}$ & $\begin{array}{l}\text { saprotrophic, } \\
\text { cellulolytic }\end{array}$ & $\begin{array}{l}\text { saprotrophic, } \\
\text { cellulolytic }\end{array}$ \\
\hline $\begin{array}{l}\text { Genome size } \\
\text { [bp] }\end{array}$ & $9,003,593$ & $9,139,763$ & $10,080,619$ & $10,350,586$ & $13,033,779$ & $14,782,125$ \\
\hline $\begin{array}{l}\text { Protein-coding } \\
\text { sequences }\end{array}$ & 7,285 & 7,388 & 8,033 & 8,043 & 9,367 & 11,599 \\
\hline $\begin{array}{l}\text { GenBank } \\
\text { accession no. }\end{array}$ & CP002830 & CP000113 & CP003389 & CP004025 & AM746676 & CP003969 \\
\hline Reference & [42] & [43] & [44] & {$[45]$} & [46] & [47] \\
\hline $\begin{array}{l}\text { \# of } \\
\text { biosynthesis } \\
\text { gene clusters }\end{array}$ & 25 & 24 & 36 & 29 & 31 & 34 \\
\hline $\begin{array}{l}\text { \# of } \\
\text { biosynthesis } \\
\text { gene clusters } \\
\text { per Mbp }\end{array}$ & 2.78 & 2.63 & 3.57 & 2.80 & 2.38 & 2.30 \\
\hline $\begin{array}{l}\text { Combined } \\
\text { length of } \\
\text { biosynthesis } \\
\text { clusters [bp] }\end{array}$ & $1,147,796$ & $1,329,413$ & $1,571,607$ & $1,672,930$ & $1,199,901$ & $1,450,537$ \\
\hline $\begin{array}{l}\text { Genome } \\
\text { portion devoted } \\
\text { to biosynthesis } \\
{[\%]}\end{array}$ & 12.75 & 14.55 & 15.59 & 16.16 & 9.21 & 9.81 \\
\hline
\end{tabular}

aNumbers and size of biosynthesis loci were determined using antiSMASH [50].

matic analysis of the DK1622 chromosome with antiSMASH indicated the presence of 24 gene clusters, which are involved in the secondary metabolism (Table 2).

Until now, six loci have been associated with isolated natural products on the basis of biosynthetic precedence and extensive metabolome analyses (Figure 1) [56,57]. While some of the retrieved compounds from $M$. xanthus DK1622 are also known from different myxobacterial species, as exemplified by the myxochelins [58-60] and myxochromides [61,62], others were initially discovered in this strain, such as the myxoprincomides [57] and the DKxanthenes [63].

The known secondary metabolites of M. xanthus DK1622 show a wide range of biological activities and can hence be expected to fulfill different ecological functions. The yellow DKxanthenes, for instance, play a crucial role in spore maturation during fruiting body formation [63]. They were also shown to possess antioxidative properties and might thus confer resistance towards oxidative stress [63]. Structurally, the DKxanthenes harbor a hydrophilic asparagine moiety attached to a hydrophobic polyene chain bearing an additional oxazoline and pyrrol ring system. Their production seems to be universal among Myxococcus strains and several derivatives varying in their polyene chain length as well as extent of methyl branching have been identified [63-65]. The myxochromides represent another pigment family commonly encountered in myxobacteria $[61,65,66]$. While their chemistry and biosynthesis have been thoroughly explored $[62,67]$, the biological function of these cyclic depsipeptides is still not clear. In contrast, the myxochelins primarily serve as siderophores for $M$. xanthus DK1622, as evidenced by their iron-responsive production and complexing properties [58,59]. Recent studies also unveiled specific enzymatic targets for these natural products $[60,68]$, which are not due to their iron affinity [69]. Myxalamids [7073] and myxovirescins [74-79] are distinguished by their potent antimicrobial activities. The former are inhibitors of electron transport in the respiratory chain. They were shown to block the electron flow at complex I of mitochondria (NADH:ubiquinone oxidoreductase) in a competitive manner, but do not act on bacterial complex I $[71,72]$. This explains why the myxalamids are mainly active against fungi [71]. 
Table 2: Biosynthetic gene clusters in the genome of $M$. xanthus DK1622 and their predicted or known products. ${ }^{a}$

\begin{tabular}{lllll} 
No. & Cluster location & Type & Actual or predicted product & Estimated size [kb] \\
\hline 1 & MXAN_0889-MXAN_0906 & terpene & carotenoid & 21.0 \\
2 & MXAN_1276-MXAN_1312 & NRPS & dipeptide & 46.3 \\
3 & MXAN_1508-MXAN_1543 & other & unknown & 44.4 \\
4 & MXAN_1588-MXAN_1624 & NRPS & hexapeptide & 64.6 \\
5 & MXAN_2782-MXAN_2814 & NRPS/PKS (type I) & unknown & 51.8 \\
6 & MXAN_2847-MXAN_2864 & lantipeptide & class II lantipeptide & 23.3 \\
7 & MXAN_3447-MXAN_3479 & PKS (type I) & unknown & 46.7 \\
8 & MXAN_3551-MXAN_3559 & bacteriocin & bacteriocin & 10.9 \\
9 & MXAN_3602-MXAN_3658 & NRPS/PKS (type I) + NRPS & lipopeptide + myxochelin & 168.4 \\
10 & MXAN_3763-MXAN_3797 & NRPS/PKS (type I) & myxoprincomide & 82.8 \\
11 & MXAN_3917-MXAN_3957 & trans-AT-PKS/NRPS & myxovirescin & 109.6 \\
12 & MXAN_3986-MXAN_4020 & NRPS/PKS (type I) & lipopeptide & 70.3 \\
13 & MXAN_4057-MXAN_4100 & PKS (type I)/NRPS & myxochromide & 69.0 \\
14 & MXAN_4156-MXAN_4166 & bacteriocin & bacteriocin & 11.7 \\
15 & MXAN_4271-MXAN_4312 & PKS (type I)/NRPS & DKxanthene & 76.9 \\
16 & MXAN_4384-MXAN_4402 & NRPS/PKS (type I) & unknown & 48.2 \\
17 & MXAN_4404-MXAN_4438 & NRPS/PKS (type I) & lipopeptide & 70.0 \\
18 & MXAN_4508-MXAN_4549 & NRPS/PKS (type I) & myxalamide & 92.7 \\
19 & MXAN_4545-MXAN_4561 & lantipeptide & lantipeptide & 26.2 \\
20 & MXAN_4578-MXAN_4618 & NRPS & lipopeptide & 79.4 \\
21 & MXAN_4951-MXAN_4960 & bacteriocin & bacteriocin & 10.8 \\
22 & MXAN_6241-MXAN_6257 & terpene & geosmin & 22.2 \\
23 & MXAN_6377-MXAN_6414 & lantipeptide/ladderane/ PKS (type II) & unknown & 41.1 \\
24 & MXAN_6618-MXAN_6659 & PKS (type III) & alkylresorcinol & 41.1
\end{tabular}

aAll predictions are according to [50], except for the assignment of the myxochelin gene cluster.

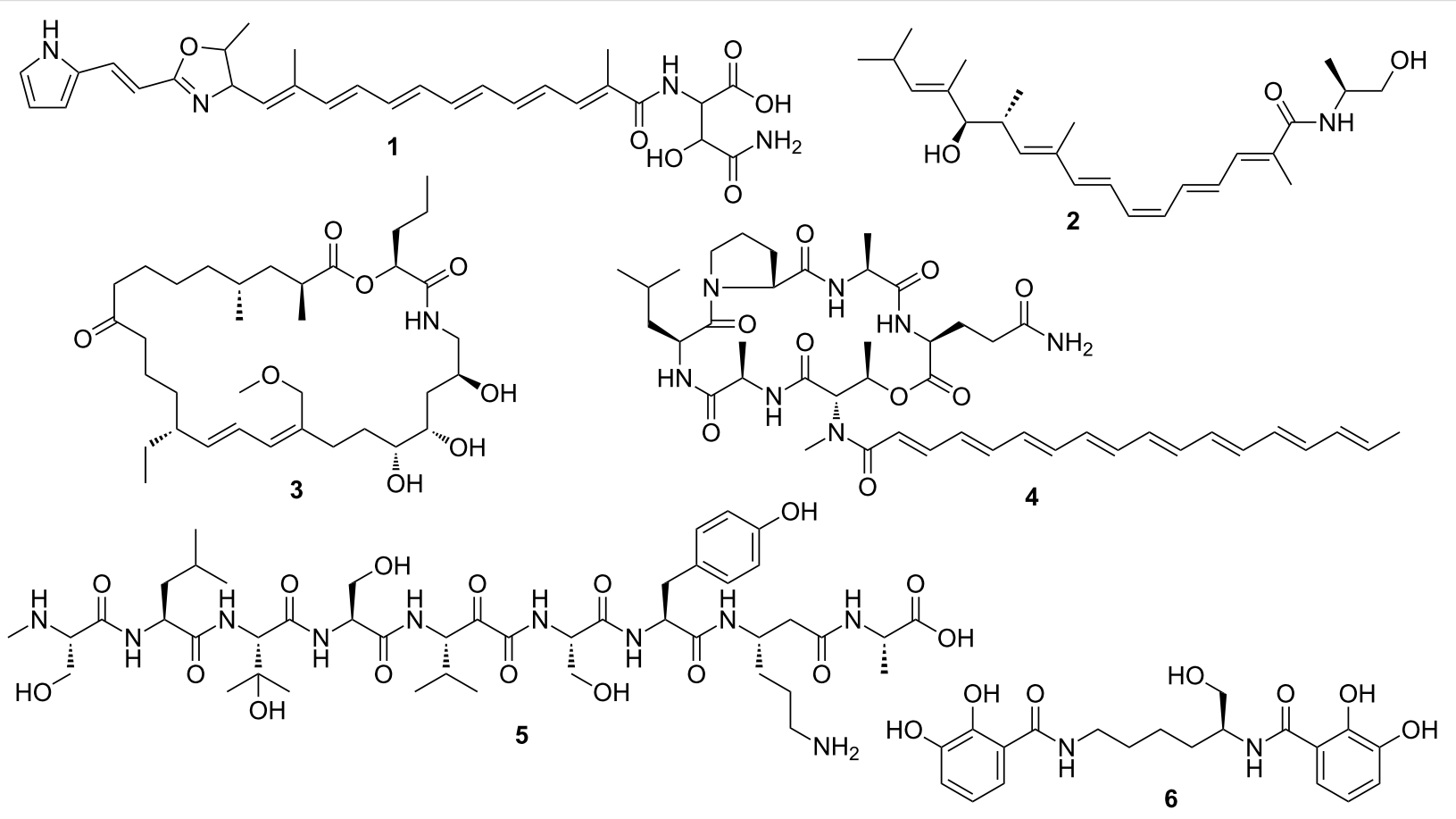

Figure 1: Natural products isolated from M. xanthus DK1622. DKxanthene-534 (1); myxalamid B (2); myxovirescin $A_{1}$ (3); myxochromide $A_{3}(4)$; myxoprincomide (5); myxochelin A (6). 
The myxovirescins comprise a family of closely related antibiotics featuring a distinctive 28 -membered macrolide ring. First discovered by Rosenberg et al. in M. xanthus TA [74], the myxovirescins were later also reported from other myxobacterial isolates, including strain DK1622 [75-79]. Myxovirescins are excreted during late exponential and early stationary growth phase and display strong inhibitory activities on growing bacterial cells, even when applied at concentrations less than $5 \mu \mathrm{g} / \mathrm{mL}$. Toxicity against eukaryotic cells was not observed [74,80]. Myxovirescin $A_{1}$ was found to be particularly effective against enterobacteria with a minimal inhibitory concentration (MIC) of $1 \mu \mathrm{g} / \mathrm{mL}$ [75]. Its mode of action was deduced after genetic characterization of myxovirescin-resistant $E$. coli mutants [81]. The antibiotic interferes with cell-wall biosynthesis by inhibiting a novel target, i.e., the type II signal peptidase LspA, which is involved in the maturation of lipoproteins required for murein biosynthesis [81].

Myxovirescin $\mathrm{A}_{1}$ (also known as antibiotic TA) and its derivatives seem to be of particular importance for the predatory lifestyle of M. xanthus DK1622. Gene deletion experiments demonstrated that a loss of myxovirescin biosynthesis significantly affects the ability of the myxobacterium to kill actively growing E. coli cells [82]. Furthermore, myxovirescin-resistant E. coli strains were shown to be largely resistant against predation by DK1622, demonstrating for the first time a clear link between antibiotic production and predation. However, myxovirescins cannot be considered as universal predatory weapons for M. xanthus DK1622, as the macrolides have no effects on the Gram-positive prey bacterium Micrococcus luteus [82]. It remains unclear whether as yet unidentified antibiotics from the DK1622 metabolome complement the bioactivity of myxovirescins and, thereby, expand the prey spectrum. Alternatively, it is possible that the killing of M. luteus involves a different predation strategy (e.g., attack with hydrolytic enzymes).

In any case, the coordinate production of antibiotics, such as myxovirescin A, requires a tight regulatory network in predatory myxobacteria [80]. This is also reflected in the genome of M. xanthus DK1622, which features an unusual high duplication frequency of genes encoding regulatory proteins like serine-threonine kinases and enhancer binding proteins (EBPs) [43]. EBPs are regulatory proteins influencing the transcription by binding to a specific enhancer-like element (ELE) sequence located in close vicinity to the corresponding promoter in a $\delta 54$ dependent manner [83]. Two EBPs of M. xanthus DK1622, namely HsfA and MXAN4899, have recently been identified as transcriptional regulators of secondary metabolism via DNA-protein pull-down assays [84]. Knock-out studies revealed that both EBPs are necessary for the formation of intact fruiting body and sporulation. DKxanthene biosynthesis was strongly influenced by HsfA and MXAN4899, respectively, which is in good agreement with the biological function of this compound class [63]. Furthermore, the two EBPs were linked to the regulation of the myxovirescin pathway and motility. While HsfA acted as a repressor of the myxovirescin production, MXAN4899 could exert enhancing or inhibitory effects depending on the nutrition status of the myxobacterium. The findings of this study attested a complex regulatory network to M. xanthus DK1622, in which development, predation, and motility are clearly connected to secondary metabolism [84].

Lastly, it should be mentioned that genomic data might also provide the explanation for the predatory behavior of some myxobacteria. Nutritional studies had shown that $M$. xanthus cannot be grown in the absence of branched-chain amino acids [85]. Consistent with these results, the genome of strain DK1622 lacks $i l v C$ and $i l v D$ genes, which are required for the biosynthesis of these amino acids. It was hence speculated that predation might compensate for this deficiency [43]. Analysis of the other myxobacterial genomes now lends support to this assumption. We found the absence of $i l v C$ and $i l v D$ to be a consistent trait in the bacteriolytic Myxococcus and Corallococcus strains, whereas the genomes of the cellulolytic Sorangium strains harbor well-conserved homologs of both genes.

\section{Antibiotics from myxobacteria with a possible role in predation}

The following listing highlights few selected antibiotics from myxobacteria in the context of predation. For a comprehensive overview of bioactive compounds from myxobacteria and their modes of action, the reader is referred to the excellent review articles by König et al. [33] and Müller et al. [86].

Gulmirecins: The gulmirecins were found in a culture broth of the predatory myxobacterium Pyxidicoccus fallax HKI 727 (Figure 2) [87]. Their discovery is an illustrative example on how new antibiotics can be retrieved from predatory bacteria. The isolation of predatory bacteria from soil is typically achieved by means of baiting techniques. For this, a pea-sized sample is placed on a nutrient-poor agar medium, that was previously inoculated with potential prey microbes [88-90]. These organisms serve as attractants that will allow the enrichment of any predators present in the soil sample. Baiting techniques have proven to be particularly useful for the recovery of bacteriolytic myxobacteria, as swarming and fruiting body formation facilitate the separation from other microorganisms [91]. If the isolation procedure is repeated with varying "food organisms", it becomes possible to select for myxobacteria that can be distinguished by their preference for certain prey bacteria. This 


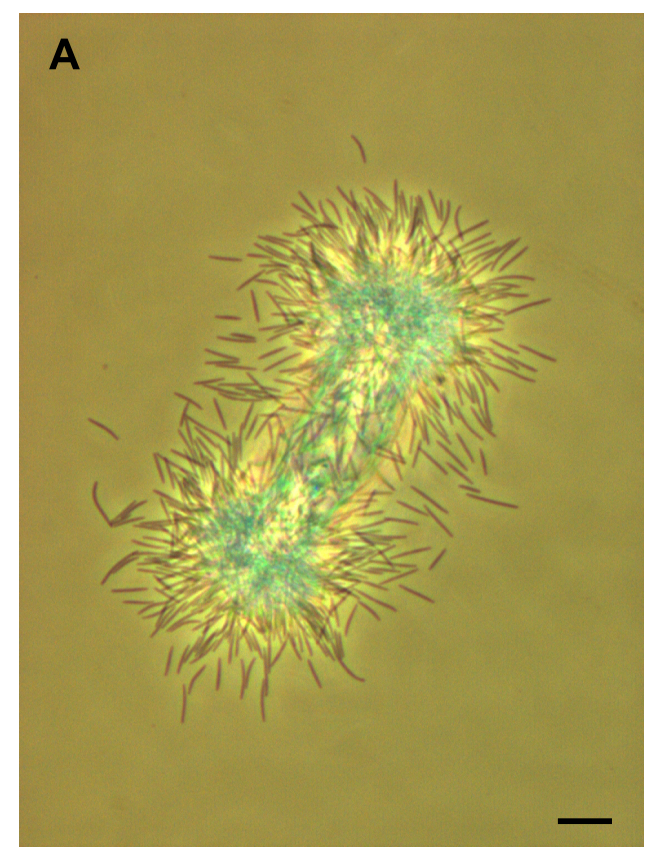

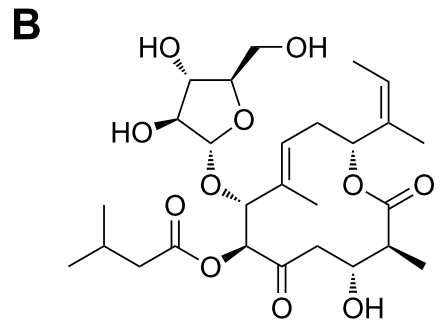

7

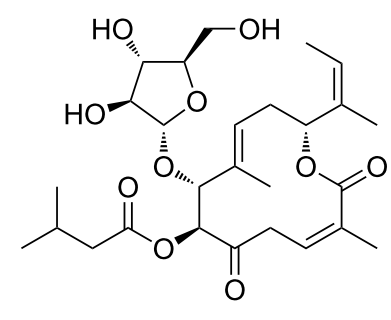

9<smiles>C/C=C(/C)C(C/C=C(\C)C(OC1OC(CO)C(O)C1O)C(O)C(=O)CCC(C)C(=O)O)OC</smiles>

8

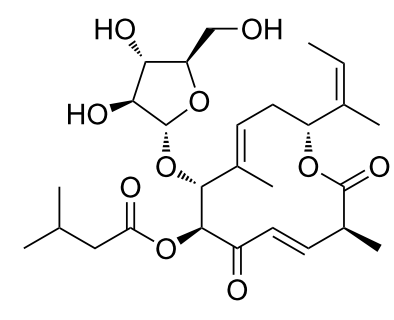

10

Figure 2: Vegetative cells of $P$. fallax HKI 727 under a phase-contrast microscope (K. Martin, unpublished). Bar is $10 \mu \mathrm{m}$ (A). Structures of gulmirecin A (7), gulmirecin B (8), disciformycin A (9), and disciformycin B (10) (B).

approach was also used during the isolation of strain HKI 727 , which readily consumed the prey bacterium Bacillus subtilis, but not Escherichia coli. Further tests revealed that $P$. fallax HKI 727 exhibits a prey range that is restricted to Gram-positive bacteria. Culture extracts of strain HKI 727 showed a consistent antimicrobial profile, i.e., they were highly active against Gram-positive bacteria. Bioactivity-guided fractionation then led to the identification of the gulmirecins as the active principles [87].

Chemically, the gulmirecins form a novel class of antibiotics together with the disciformycins [92], which were discovered in a different $P$. fallax strain upon a large-scale screening. The distinctive 12-membered macrolide scaffold in these natural products features an arabinose moiety (Figure 2), which is only rarely observed in bacterial polyketides. The main difference between gulmirecins A and B is the presence or absence of an isovalerate substituent. Comparison with the bioactivity data of the disciformycins suggests that the isovalerate motive is important for the antibacterial activity. Due to their potent effects against human pathogenic staphylococci as well as negligible toxicity, gulmirecins A and disciformycin B have become promising candidate compounds for the design of new antibiotics $[93,94]$. Since the gene loci that are involved in their biosyntheses have been identified [87,92], it might even be possible to genetically engineer further derivatives in the future. The close correlation between the activity profile of the gulmirecins and the prey range of strain HKI 727 further suggests that isolation procedures for predatory bacteria can be directed in order to obtain strains producing antibiotics against specific pathogens.

Myxopyronins and corallopyronins: The myxopyronins were first reported in 1983 from a culture supernatant of Myxococcus fulvus Mxf50 [95,96]. Later, the structurally related corallopyronins were found in different strains of Corallococcus coralloides [97-99]. Myxopyronins and corallopyronins share a common scaffold composed of a central pyrone ring carrying two flexible side chains (Figure 3). Structural variability manifests in the so-called western side chain, which ranges from 10 (myxopyronin A) up to 18 carbon atoms (corallopyronin B). In contrast, the eastern chain is conserved among all members and features a terminal methyl carbamate moiety. Differences in the architectures of the respective biosynthetic assembly lines were recently shown to account for the diverging frameworks of the western chain [100-102].

Myxopyronins and corallopyronins turned out to be highly active against Gram-positive bacteria with MIC values between 0.1 and $1.0 \mu \mathrm{g} / \mathrm{mL}$ for Staphylococcus aureus, whereas their inhibitory effects on Gram-negative strains are in general much weaker. Gram-negative bacteria of the genus Wolbachia, which have emerged as a new target for filariasis control, constitute a significant exception [103]. Already in the 1980s, incorporation studies with labeled precursors revealed the inhibition of prokaryotic RNA polymerase (RNAP) as mode of action for myxopyronins and corallopyronins $[95,97]$. Later on, mutagen- 


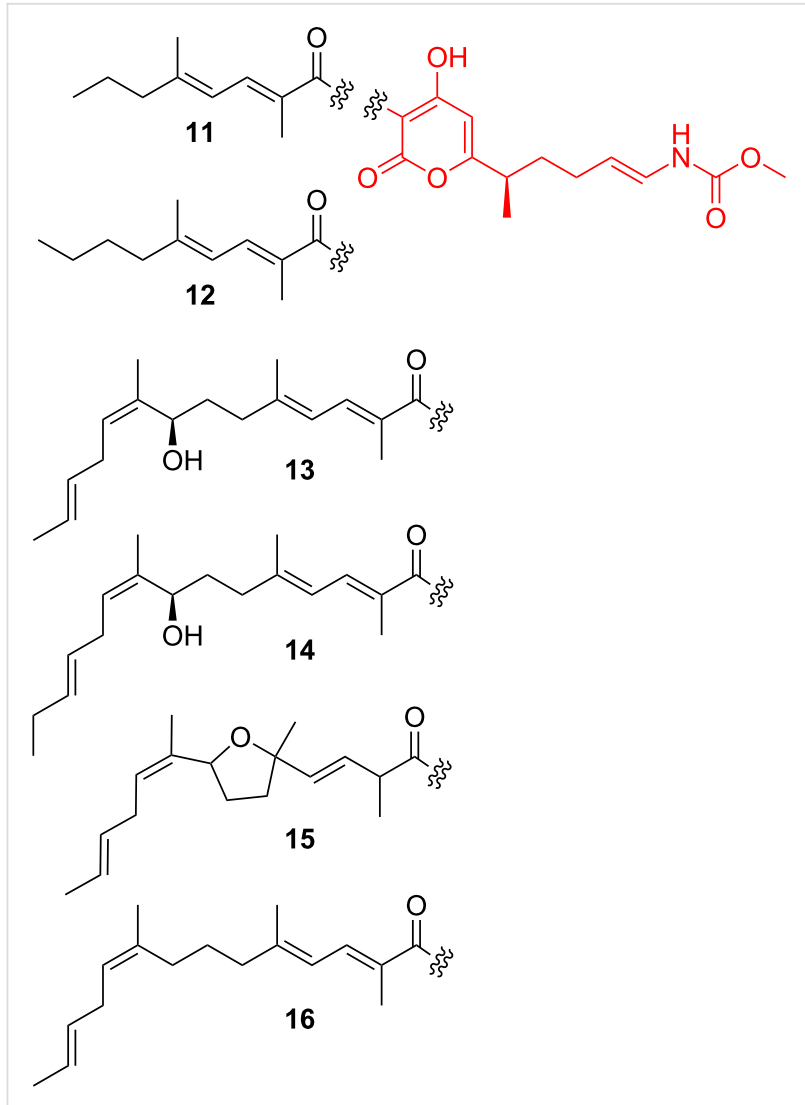

Figure 3: Structures of myxopyronins $A$ (11) and $B$ (12), corallopyronins $A(13), B(14)$ and $C$ (15), as well as precorallopyronin A (16).

esis experiments as well as binding studies indicated that the antibiotics interact with the RNAP switch region [104,105], which acts as a hinge mediating conformational changes during transcription [106]. During early stages of transcriptional initiation, the RNAP clamp possesses an opened form in order to allow binding of the promoter DNA to the active-center cleft. At late transcriptional initiation and elongation, the clamp changes into a closed position to retain the DNA inside the active-center cleft. After binding to the switch region, myxopyronins and corallopyronins prevent the opening of the clamp [104,105].

Prey bacteria that develop resistance against corallopyronin, e.g., due to a rpoB mutation, also become resistant towards predation by $C$. coralloides [82]. It is thus likely that corallopyronin is produced by myxobacteria to facilitate feeding on other bacteria.

Althiomycin: The antibiotic althiomycin (Figure 4) had been initially discovered in cultures of Streptomyces althioticus [107], before it was also reported from strains of Myxococcus virescens, M. xanthus, and Cystobacter fuscus [108]. The pentapeptide is broadly active against Gram-positive as well as
Gram-negative bacteria and was shown to selectively inhibit bacterial protein synthesis. Its specific site of inhibition is the 50S subunit of the ribosome, where althiomycin interferes with the peptidyl transferase reaction $[109,110]$. The althiomycin biosynthetic gene cluster was recently identified in M. xanthus DK897 by a combination of retrobiosynthetic analysis and gene inactivation [111]. Two open reading frames (ORFs) encoding for a nonribosomal peptide synthetase (NRPS) and a NRPS/ polyketide synthase (PKS) hybrid were found to be involved in the assembly of the core structure. Furthermore, the cluster included four additional ORFs that have specific roles in tailoring reactions and drug resistance [111].

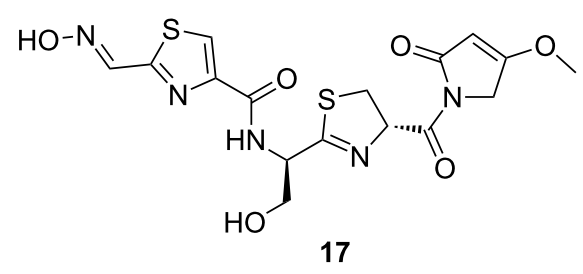

Figure 4: Structure of althiomycin (17).

Unlike the ubiquitous DKxanthenes or myxochelins, althiomycin is only produced by a few members of the species M. xanthus [65]. For instance, the model strain DK1622 lacks the althiomycin biosynthesis genes and is even sensitive against this antibiotic [111]. In a comprehensive chemical analysis of 98 different $M$. xanthus strains, althiomycin was never observed together with myxovirescins [65]. It is hence very tempting to speculate that the predatory weapon myxovirescin could have been replaced by another potent antibiotic. Considering the dispersal of althiomycin biosynthesis genes in many taxonomically unrelated bacteria [112], it appears possible that some myxobacteria acquired the respective locus via horizontal gene transfer.

Cystobactamids: The cystobactamids were recently isolated from a Cystobacter sp. and represent a novel class of NRPSderived antimicrobial peptides [113]. Cystobactamids 919-1 and 919-2 (Figure 5) display an unusual aromatic scaffold composed of $p$-nitrobenzoic acid and four $p$-aminobenzoic acid (PABA)-derived moieties. The latter vary in their oxidation and substitution pattern, which may even comprise rare isopropoxy groups. The two unmodified PABA residues in compounds 919-1 and 919-2 are connected via an iso- $\beta$-methoxyasparagine or a $\beta$-methoxyasparagine unit, respectively. In contrast, the tripeptidic cystobactamid 507 seems to be either a biosynthetic byproduct or a degradation fragment of its larger congeners. All cystobactamids lack antifungal and cytotoxic properties, but they exhibit significant antibacterial activities. Especially deriv- 


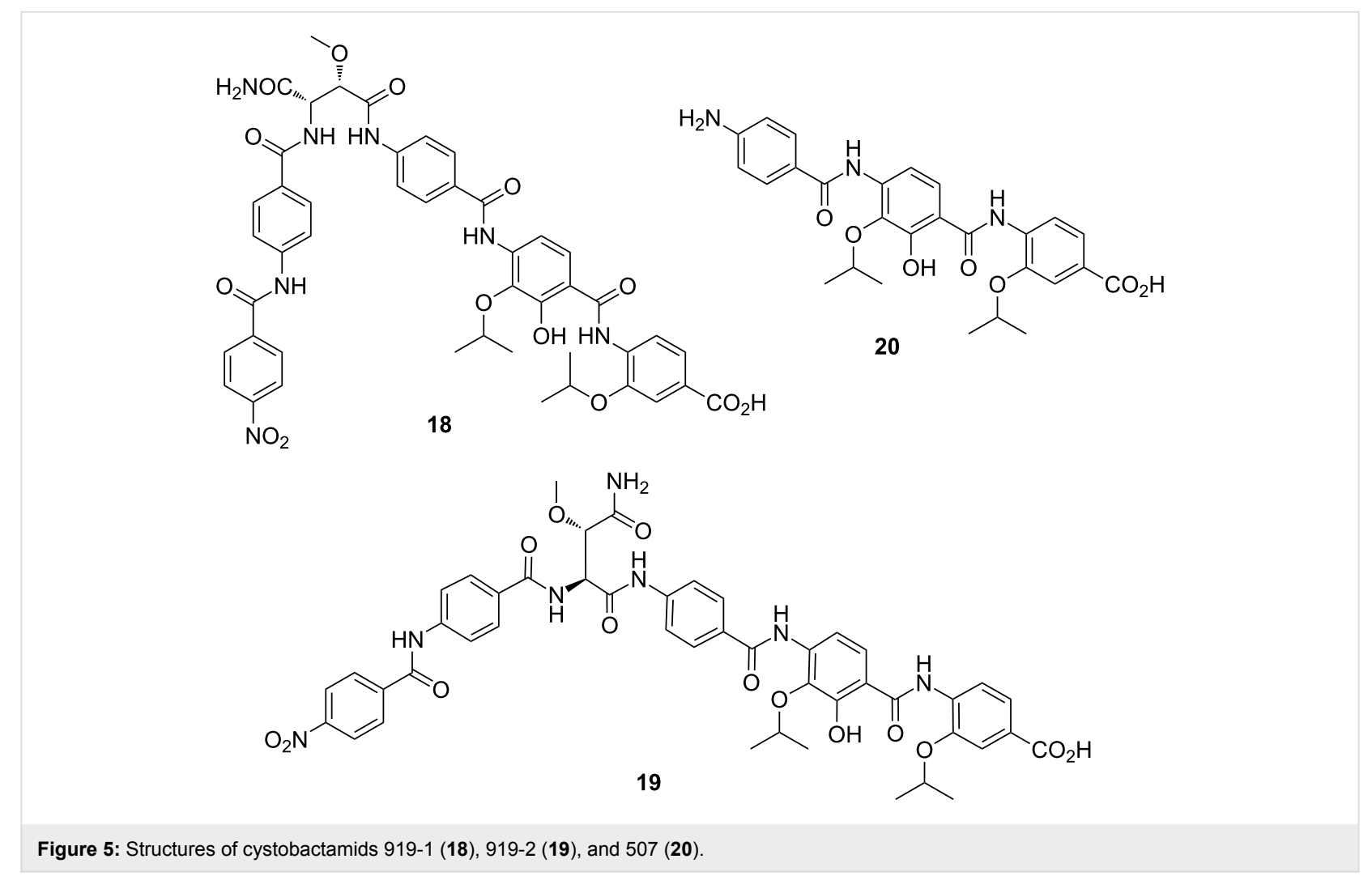

ative 919-2 (19) possesses strong inhibitory effects on the growth of Gram-positive and Gram-negative bacteria. Susceptible bacteria include Acinetobacter baumannii, which is a frequent inhabitant of soil, but has received even more attention as a causative agent of hard-to-treat nosocomial infections [113]

Analysis of the cystobactamid biosynthesis gene cluster led to the identification of a gene encoding a putative resistance factor. This discovery was the starting point for resolving the molecular target of these antibiotics. Subsequent assays confirmed that the cystobactamids act as bacterial DNA gyrase inhibitors [113]. Whether or not the cystobactamids are involved in predation has not been investigated yet. Their potent activity at nanomolar concentrations against a broad range of bacteria would undoubtedly make them excellent molecules for hunting down prey.

\section{Biology and biosynthetic potential of Herpeto- siphon spp.}

Taxonomically, the genus Herpetosiphon belongs to the class Chloroflexi within the homonymous phylum. Members of this phylum are metabolically highly diverse, including dehalorespiring anaerobes besides aerobic $\mathrm{CO}$-oxidizing thermophiles, chlorophototrophs and chemoheterotrophs [114-116]. Characteristic features in the class Chloroflexi comprise a fila- mentous morphology and gliding motility. The associated bacteria stain Gram-negative, albeit lacking a lipopolysaccharide-containing outer membrane [117], and they typically grow phototrophically under anoxic conditions [118]. In stark contrast to its relatives, Herpetosiphon is not capable of photosynthesis. It has been proposed that the genus diverged from the major lineage upon loss of its photosystem and has shifted to a saprophytic, facultative predatory lifestyle [114]. Herpetosiphon spp. seem to be widely distributed in soil and freshwater environments [119], where they attack and digest a multitude of bacteria [11]. Akin to myxobacteria, they are assumed to practice group predation [6]. Actually, the genus only includes two validly described species, namely $H$. aurantiacus and $H$. geysericola. The genome of $H$. aurantiacus $114-95^{\mathrm{T}}$, which is the type species of the entire genus, was fully sequenced and annotated [12]. Furthermore, a draft genome sequence of $H$. geysericola has recently become available [120]. The circular chromosomes of the two Herpetosiphon strains are of comparable size, i.e., 6.35 and $6.14 \mathrm{Mbp}$, whereas their phototrophic relatives have smaller replicons that range from 4.68 to $5.80 \mathrm{Mbp}$ [12]. It thus appears as if there has been an enlargement of the predator's genomes. Some of the expansion that is evident results from the acquisition of genes involved in secondary metabolism [121]. While the potential of Chloroflexus and Roseiflexus spp. for the production of natural products is negligible [122], the Herpetosiphon genomes contain a signifi- 
cant number of biosynthetic loci (Table 3). Unlike actinomycete genomes, which are particularly rich in polyketide pathways [123], the Herpetosiphon chromosomes were found to be dominated by NRPS or mixed NRPS/PKS clusters. This situation is hence quite similar to myxobacteria [56]. An unexpected finding, however, was the discovery of an enediyne PKS gene in $H$. aurantiacus $114-95^{\mathrm{T}}$. Enediynes are highly potent antibiotics, causing DNA-strand scissions. Although an impressive number of 87 enediyne clusters could be identified in sequencing projects over the past years, comparatively few loci were retrieved from microbes outside the actinobacteria [124]. This suggests an event of horizontal gene transfer (HGT) in H. aurantiacus $114-95^{\mathrm{T}}$. Analysis of a large NRPS/PKS cluster in the same strain yielded even more compelling evidence for HGT. Not only is the respective cluster enclosed by a number of transposon fragments, it also features an above-average $\mathrm{G}+\mathrm{C}$ content of $\approx 66 \%$ (the genome standard is $50.9 \%$ ) as well as significant $\mathrm{G}+\mathrm{C}$ shifts in its border regions [12]. The observation that HGT is in part responsible for the accumulation of biosynthesis genes is again reminiscent of the predatory myxobacteria [43].

\section{Natural products from Herpetosiphon spp.}

While myxobacteria are already known as a promising source for natural product research $[31,32]$, the genus Herpetosiphon has been almost completely ignored in the field. It is therefore no surprise that to date only three classes of secondary metabolites have been reported from this genus (Figure 6). Siphonazole and its $O$-methyl derivative were the first natural products to be isolated from a Herpetosiphon strain [125]. The two compounds exhibit an unusual molecular architecture featuring two oxazole rings connected by a two-carbon tether and a terminal 2,4-pentadienylamine moiety. Feeding experiments as well as biosynthetic reasoning indicated that the siphonazoles originate from a mixed PKS/NRPS pathway [125]. Both bisoxazoles were found to possess anticancer properties, but they lack antimicrobial activities [126]. In case the siphonazoles should contribute to the predatory behavior of the producing strain, they must exert more subtle effects than those described for myxovirescins and gulmirecins.

Efforts to identify secondary metabolites from the H. aurantiacus type strain $114-95^{\mathrm{T}}$ led to the discovery of auriculamide (22) [127]. This natural product is composed of a 2-hydroxy-3-methylvalerate and a 2-amino-1-(3-chloro-4hydroxy-phenyl)pentan-3-one residue. A retrobiosynthetic analysis allowed the assignment of the gene cluster, which is responsible for the production of auriculamide. According to the current biosynthetic model, the scaffold of auriculamide is assembled on an NRPS/PKS enzyme complex. A decarboxyl-

\begin{tabular}{|c|c|c|c|c|c|c|}
\hline & $\begin{array}{l}\text { Herpetosiphon } \\
\text { aurantiacus } \\
114-95^{\top}\end{array}$ & $\begin{array}{l}\text { Herpetosiphon } \\
\text { geysericola GC-42 }\end{array}$ & $\begin{array}{l}\text { Chloroflexus } \\
\text { aurantiacus } \\
\mathrm{J}-10-\mathrm{fl}\end{array}$ & $\begin{array}{l}\text { Chloroflexus } \\
\text { aggregans } \\
\text { DSM } 9485\end{array}$ & $\begin{array}{l}\text { Roseiflexus } \\
\text { castenholzii } \\
\text { DSM } 13941\end{array}$ & $\begin{array}{l}\text { Roseiflexus } \\
\text { sp. RS-1 }\end{array}$ \\
\hline $\begin{array}{l}\text { Order } \\
\text { Nutrition }\end{array}$ & $\begin{array}{l}\text { Herpetosiphonales } \\
\text { saprotrophic } \\
\text { predatory }\end{array}$ & $\begin{array}{l}\text { Herpetosiphonales } \\
\text { saprotrophic } \\
\text { predatory }\end{array}$ & $\begin{array}{l}\text { Chloroflexales } \\
\text { phototrophic }\end{array}$ & $\begin{array}{l}\text { Chloroflexales } \\
\text { phototrophic }\end{array}$ & $\begin{array}{l}\text { Chloroflexales } \\
\text { phototrophic }\end{array}$ & $\begin{array}{l}\text { Chloroflexales } \\
\text { phototrophic }\end{array}$ \\
\hline $\begin{array}{l}\text { Chromosome } \\
\text { size [bp] }\end{array}$ & $6,346,587$ & $6,140,412$ (draft) & $5,258,541$ & $4,684,931$ & $5,723,298$ & $5,801,598$ \\
\hline $\begin{array}{l}\text { Protein-coding } \\
\text { sequences }\end{array}$ & 5,577 & 4,688 & 3,853 & 3,679 & 4,492 & 4,639 \\
\hline $\begin{array}{l}\text { GenBank } \\
\text { accession no. }\end{array}$ & CP000875 & $\begin{array}{l}\text { NZ } \\
\text { LGKPP00000000 }\end{array}$ & СР000909 & СР001337 & CP000804 & СР000686 \\
\hline Reference & {$[12]$} & {$[120]$} & {$[122]$} & GenBank & GenBank & GenBank \\
\hline $\begin{array}{l}\text { \# of biosynthesis } \\
\text { gene clusters }\end{array}$ & 14 & 9 & 2 & 4 & 4 & 4 \\
\hline $\begin{array}{l}\text { \# of biosynthesis } \\
\text { gene clusters } \\
\text { per Mbp }\end{array}$ & 2.21 & 1.47 & 0.38 & 0.43 & 0.70 & 0.69 \\
\hline $\begin{array}{l}\text { Combined } \\
\text { length of } \\
\text { biosynthesis } \\
\text { clusters [bp] }\end{array}$ & 821,829 & 300,554 & 42,182 & 42,170 & 117,838 & 117,958 \\
\hline $\begin{array}{l}\text { Genome portion } \\
\text { devoted to } \\
\text { biosynthesis [\%] }\end{array}$ & 12.95 & 4.89 & 0.80 & 0.90 & 2.06 & 2.03 \\
\hline
\end{tabular}

${ }^{a}$ Numbers and size of biosynthesis loci were determined using antiSMASH [50]. 


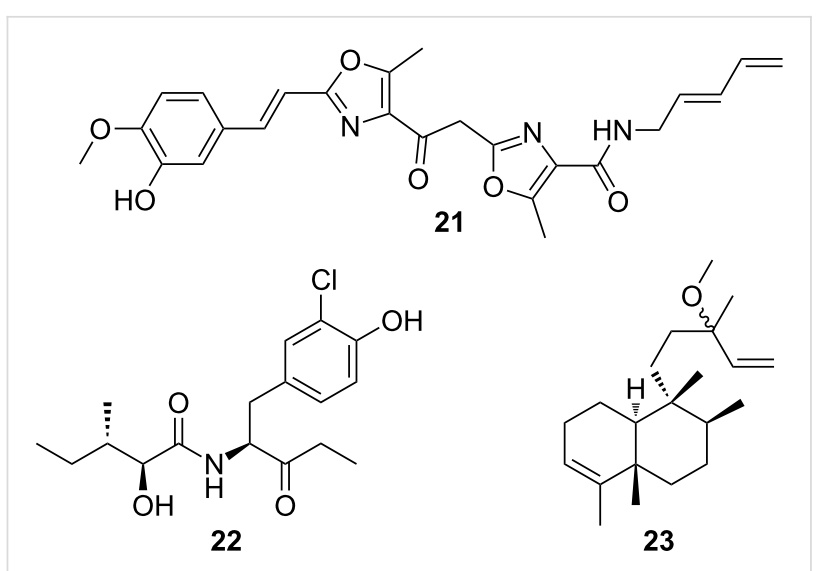

Figure 6: Structures of natural products isolated from Herpetosiphon spp.: siphonazole (21); auriculamide (22); (+)-O-methylkolavelool (23).

ation reaction was proposed to shorten the off-loaded carboxylic acid and to give rise to the unusual end group of the natural product [127]. Whether auriculamide possesses antibiotic properties is still open. The low fermentation yield prevented biological testing of the isolated compound.

More recently, the terpenome of $H$. aurantiacus $114-95^{\mathrm{T}}$ received some attention. Researchers found two genes in the chromosome, the enzymatic products of which exhibited high sequence similarity to proteins that are responsible for the biosynthesis of tuberculosinol and isotuberculosinol in Mycobacterium tuberculosis [128]. Following in vitro studies of the two Herpetosiphon enzymes as well as a reconstitution of the entire associated pathway, (+)-O-methylkolavelool was identified as a metabolic product. Subsequent GC-MS analyses confirmed that this previously unknown diterpene is actually produced by the predatory bacterium [128].

From genomic data, it is evident that the genus Herpetosiphon harbors a significant potential for the biosynthesis of natural products. The fact that no antibiotics have been described from this bacterium yet is in our opinion most likely due to a lack of adequate studies. Similar to other neglected producer organisms [129], the genus Herpetosiphon can be expected to yield many previously unknown natural products.

\section{Conclusion}

Bacteria practicing group predation possess comparatively large replicons with an average size of 6.0 to $6.3 \mathrm{Mbp}$ in case of Lysobacter and Herpetosiphon spp., or $9.6 \mathrm{Mbp}$ in case of Myxococcus and Corallococcus spp. [12,37,49]. Although the genome size must not necessarily exceed the most closely related non-predatory species, as shown for the myxobacteria, a distinctive feature between predatory and non-predatory strains is the density of biosynthetic loci. In other words, families of genes encoding the production of secondary metabolites were consistently found to be overrepresented in the genomes of predatory bacteria. This observation may reflect a need for specialized molecules that coordinate swarm formation or mediate prey killing. The assumption that the extended biosynthetic capacities are due to the predatory lifestyle can, however, not be verified, because only a small fraction of the corresponding secondary metabolomes have been explored. Even in case of model organisms, which were subject of extensive chemical investigations, such as M. xanthus DK1622, the products of most biosynthetic pathways await their discovery. On the other hand, there is now strong evidence that compounds, such as the myxovirescins or corallopyronins, are used by their producers to enable feeding on certain prey bacteria [82]. The loss of these antibiotics or, alternatively, a resistance development of the prey organism could not be compensated by the predator and always resulted in a restricted prey spectrum [82]. Regarding the available information on the chemistry of predatory myxobacteria, it seems likely that every strain has the potential to produce at least a single class of natural products with potent antibacterial activity. The high recovery rate of myxovirescins and corallopyronins in strains of Myxococcus xanthus and Corallococcus coralloides $[65,100]$ suggests a correlation between taxonomy and secondary metabolism. The discovery of the structurally related gulmirecins and disciformycins in different strains of Pyxidicoccus fallax [87,92] further supports the idea of species-specific antibiotics. Is the analysis of new $M$. xanthus isolates hence futile in terms of antibiotic discovery? - The observation of $M$. xanthus strains producing althiomycin instead of myxovirescins indicates the opposite, although the chance for retrieving antibiotics other than myxovirescins from this species might be low [65]. However, it should not be ignored that the activity profile of the identified antibiotics from M. xanthus does not cover the entire prey spectrum of this predator.

In summary, predatory bacteria are a promising source to find antibiotics, as these compounds confer a clear advantage to feed on prey organisms. New compound classes can most likely be expected from hardly studied genera and species. Also, it seems advisable to consider the prey preference of a bacterial hunter when searching for antibiotics that are active against selected pathogens.

\section{Acknowledgements}

M.N. gratefully acknowledges the Bundesministerium für Bildung und Forschung for supporting the research involving the discovery of antibiotics from predatory bacteria (03ZZ0808A) within the program InfectControl 2020. We thank Karin Martin (Hans-Knöll-Institute Jena) for providing the micrograph of Pyxidicoccus fallax HKI 727. 


\section{References}

1. Matz, C.; Kjelleberg, S. Trends Microbiol. 2005, 13, 302-307. doi:10.1016/j.tim.2005.05.009

2. Pernthaler, J. Nat. Rev. Microbiol. 2005, 3, 537-546. doi:10.1038/nrmicro1180

3. Chesson, P. Annu. Rev. Ecol. Syst. 2000, 31, 343-366. doi:10.1146/annurev.ecolsys.31.1.343

4. Jousset, A. Environ. Microbiol. 2012, 14, 1830-1843. doi:10.1111/j.1462-2920.2011.02627.x

5. Rønn, R.; Vestergård, M.; Ekelund, F. Acta Protozool. 2012, 51, 223-235.

6. Jurkevitch, E. Microbe 2007, 2, 67-73.

7. Davidov, Y.; Jurkevitch, E. BioEssays 2009, 31, 748-757. doi:10.1002/bies.200900018

8. Guerrero, R.; Esteve, I.; Pedrós-Alió, C.; Gaju, N. Ann. N. Y. Acad. Sci. 1987, 503, 238-250. doi:10.1111/j.1749-6632.1987.tb40611.x

9. Bengtson, S. Paleontol. Soc. Pap. 2002, 8, 289-318.

10. Casida, L. E. Appl. Environ. Microbiol. 1983, 46, 881-888.

11. Quinn, G. R.; Skerman, V. B. D. Curr. Microbiol. 1980, 4, 57-62. doi:10.1007/BF02602893

12. Kiss, H.; Nett, M.; Domin, N.; Martin, K.; Maresca, J. A.; Copeland, A.; Lapidus, A.; Lucas, S.; Berry, K. W.; Del Rio, T. G.; Dalin, E.; Tice, H.; Pitluck, S.; Richardson, P.; Bruce, D.; Goodwin, L.; Han, C.; Detter, J. C.; Schmutz, J.; Brettin, T.; Land, M.; Hauser, L.; Kyrpides, N. C.; Ivanova, N.; Göker, M.; Woyke, T.; Klenk, H.-P.; Bryant, D. A. Stand. Genomic Sci. 2011, 5, 356-370. doi:10.4056/sigs. 2194987

13. Sockett, R. E. Annu. Rev. Microbiol. 2009, 63, 523-539. doi:10.1146/annurev.micro.091208.073346

14. Morgan, A. D.; MacLean, R. C.; Hillesland, K. L.; Velicer, G. J. Appl. Environ. Microbiol. 2010, 76, 6920-6927. doi:10.1128/AEM.00414-10

15. Casida, L. E., Jr. Int. J. Syst. Bacteriol. 1982, 32, 339-345. doi:10.1099/00207713-32-3-339

16. Makkar, N. S.; Casida, L. E. Int. J. Syst. Evol. Microbiol. 1987, 37, 323-326.

17. Seccareccia, I.; Kost, C.; Nett, M. Appl. Environ. Microbiol. 2015, 81, 7098-7105. doi:10.1128/AEM.01781-15

18. Lewin, R. A. Microb. Ecol. 1997, 34, 232-236. doi:10.1007/s002489900052

19. Banning, E. C.; Casciotti, K. L.; Kujawinski, E. B. FEMS Microbiol. Ecol. 2010, 73, 254-270. doi:10.1111/j.1574-6941.2010.00897.x

20. Soo, R. M.; Woodcroft, B. J.; Parks, D. H.; Tyson, G. W.; Hugenholtz, P. PeerJ 2015, 3, e968. doi:10.7717/peerj.968

21. Casida, L. E., Jr. Microb. Ecol. 1988, 15, 1-8. doi:10.1007/BF02012948

22. Martin, M. O. J. Mol. Microbiol. Biotechnol. 2002, 4, 467-477.

23. Esteve, I.; Guerrero, R.; Montesinos, E.; Abellà, C. Microb. Ecol. 1983, 9, 57-64. doi:10.1007/BF02011580

24. Guerrero, R.; Pedrós-Alió, C.; Esteve, I.; Mas, J.; Chase, D.; Margulis, L. Proc. Natl. Acad. Sci. U. S. A. 1986, 83, 2138-2142. doi:10.1073/pnas.83.7.2138

25. Moulder, J. W. Microbiol. Rev. 1985, 49, 298-337.

26. Sockett, R. E.; Lambert, C. Nat. Rev. Microbiol. 2004, 2, 669-675. doi:10.1038/nrmicro959

27. Berleman, J. E.; Kirby, J. R. FEMS Microbiol. Rev. 2009, 33, 942-957. doi:10.1111/j.1574-6976.2009.00185.x
28. Cao, P.; Dey, A.; Vassallo, C. N.; Wall, D. J. Mol. Biol. 2015, 427, 3709-3721. doi:10.1016/j.jmb.2015.07.022

29. Mendes-Soares, H.; Velicer, G. J. Microb. Ecol. 2013, 65, 415-423. doi:10.1007/s00248-012-0135-6

30. Bode, H. B., Jr.; Müller, R. Angew. Chem., Int. Ed. 2005, 44, 6828-6846. doi:10.1002/anie.200501080

31. Nett, M.; König, G. M. Nat. Prod. Rep. 2007, 24, 1245-1261. doi:10.1039/b612668p

32. Müller, R.; Wink, J. Int. J. Med. Microbiol. 2014, 304, 3-13. doi:10.1016/j.jimm.2013.09.004

33. Schäberle, T. F.; Lohr, F.; Schmitz, A.; König, G. M. Nat. Prod. Rep. 2014, 31, 953-972. doi:10.1039/c4np00011k

34. Hayward, A. C.; Fegan, N.; Fegan, M.; Stirling, G. R. J. Appl. Microbiol. 2010, 108, 756-770. doi:10.1111/j.1365-2672.2009.04471.x

35. Xie, Y.; Wright, S.; Shen, Y.; Du, L. Nat. Prod. Rep. 2012, 29, 1277-1287. doi:10.1039/c2np20064c

36. Reichenbach, H.; Höfle, G. Biotechnol. Adv. 1993, 11, 219-277. doi:10.1016/0734-9750(93)90042-L

37. de Bruijn, I.; Cheng, X.; de Jager, V.; Gómez Expósito, R.; Watrous, J.; Patel, N.; Postma, J.; Dorrestein, P. C.; Kobayashi, D.; Raaijmakers, J. M. BMC Genomics 2015, 16, No. 991. doi:10.1186/s12864-015-2191-z

38. König, G. M.; Dávila-Céspedes, A.; Hufendiek, P.; Crüsemann, M.; Schäberle, T. F. Beilstein J. Org. Chem. 2016, submitted.

39. Kaiser, D.; Robinson, M.; Kroos, L. Cold Spring Harbor Perspect. Biol. 2010, 2, a000380. doi:10.1101/cshperspect.a000380

40. Claessen, D.; Rozen, D. E.; Kuipers, O. P.; Søgaard-Andersen, L.; van Wezel, G. P. Nat. Rev. Microbiol. 2014, 12, 115-124. doi:10.1038/nrmicro3178

41. Nan, B.; Zusman, D. R. Annu. Rev. Genet. 2011, 45, 21-39. doi:10.1146/annurev-genet-110410-132547

42. Li, Z.-F.; Li, X.; Liu, H.; Liu, X.; Han, K.; Wu, Z.-H.; Hu, W.; Li, F.-F.; Li, Y.-Z. J. Bacteriol. 2011, 193, 5015-5016. doi:10.1128/JB.05516-11

43. Goldman, B. S.; Nierman, W. C.; Kaiser, D.; Slater, S. C.; Durkin, A. S.; Eisen, J. A.; Ronning, C. M.; Barbazuk, W. B.; Blanchard, M.; Field, C.; Halling, C.; Hinkle, G.; lartchuk, O.; Kim, H. S.; Mackenzie, C.; Madupu, R.; Miller, N.; Shvartsbeyn, A.; Sullivan, S. A.; Vaudin, M.; Wiegand, R.; Kaplan, H. B. Proc. Natl. Acad. Sci. U. S. A. 2006, 103, 15200-15205. doi:10.1073/pnas.0607335103

44. Huntley, S.; Zhang, Y.; Treuner-Lange, A.; Kneip, S.; Sensen, C. W.; Søgaard-Andersen, L. J. Bacteriol. 2012, 194, 3012-3013. doi:10.1128/JB.00397-12

45. Huntley, S.; Kneip, S.; Treuner-Lange, A.; Søgaard-Andersen, L. Genome Announc. 2013, 1, e00100-13. doi:10.1128/genomeA.00100-13

46. Schneiker, S.; Perlova, O.; Kaiser, O.; Gerth, K.; Alici, A.; Altmeyer, M. O.; Bartels, D.; Bekel, T.; Beyer, S.; Bode, E.; Bode, H. B.; Bolten, C. J.; Choudhuri, J. V.; Doss, S.; Elnakady, Y. A.; Frank, B.; Gaigalat, L.; Goesmann, A.; Groeger, C.; Gross, F.; Jelsbak, L.; Jelsbak, L.; Kalinowski, J.; Kegler, C.; Knauber, T.; Konietzny, S.; Kopp, M.; Krause, L.; Krug, D.; Linke, B.; Mahmud, T.; Martinez-Arias, R.; McHardy, A. C.; Merai, M.; Meyer, F.; Mormann, S.; Muñoz-Dorado, J.; Perez, J.; Pradella, S.; Rachid, S.; Raddatz, G.; Rosenau, F.; Rückert, C.; Sasse, F.; Scharfe, M.; Schuster, S. C.; Suen, G.; Treuner-Lange, A.; Velicer, G. J.; Vorhölter, F.-J.; Weissman, K. J.; Welch, R. D.; Wenzel, S. C.; Whitworth, D. E.; Wilhelm, S.; Wittmann, C.; Blöcker, H.; Pühler, A.; Müller, R. Nat. Biotechnol. 2007, 25, 1281-1289. doi:10.1038/nbt1354 
47. Han, K.; Li, Z.-F.; Peng, R.; Zhu, L.-P.; Zhou, T.; Wang, L.-G.; Li, S.-G.; Zhang, X.-B.; Hu, W.; Wu, Z.-H.; Qin, N.; Li, Y.-Z. Sci. Rep. 2013, 3, No. 2101. doi:10.1038/srep02101

48. Blattner, F. R.; Plunkett, G., III; Bloch, C. A.; Perna, N. T.; Burland, V.; Riley, M.; Collado-Vides, J.; Glasner, J. D.; Rode, C. K.; Mayhew, G. F.; Gregor, J.; Davis, N. W.; Kirkpatrick, H. A.; Goeden, M. A.; Rose, D. J.; Mau, B.; Shao, Y. Science 1997, 277, 1453-1462. doi:10.1126/science.277.5331.1453

49. Huntley, S.; Hamann, N.; Wegener-Feldbrügge, S.; Treuner-Lange, S.; Kube, M.; Reinhardt, R.; Klages, S.; Müller, R.; Ronning, C. M.; Nierman, W. C.; Søgaard-Andersen, L. Mol. Biol. Evol. 2011, 28, 1083-1097. doi:10.1093/molbev/msq292

50. Chen, X.-J.; Han, K.; Feng, J.; Zhuo, L.; Li, Y.-J.; Li, Y.-Z. Stand. Genomic Sci. 2016, 11, No. 1. doi:10.1186/s40793-015-0121-y

51. Weber, T.; Blin, K.; Duddela, S.; Krug, D.; Kim, H. U.; Bruccoleri, R.; Lee, S. Y.; Fischbach, M. A.; Müller, R.; Wohlleben, W.; Breitling, R.; Takano, E.; Medema, M. H. Nucleic Acids Res. 2015, 43, W237-W243. doi:10.1093/nar/gkv437

52. Garcia, R.; Müller, R. The Family Polyangiaceae. In The Prokaryotes; Rosenberg, E.; DeLong, E. F.; Lory, S.; Stackebrandt, E.; Thompson, F., Eds.; Springer: Berlin, Heidelberg, 2014; pp 247-279. doi:10.1007/978-3-642-39044-9_308

53. Garcia, R.; Gerth, K.; Stadler, M.; Dogma, I. J., Jr.; Müller, R. Mol. Phylogenet. Evol. 2010, 57, 878-887. doi:10.1016/j.ympev.2010.08.028

54. Garcia, R.; Pistorius, D.; Stadler, M.; Müller, R. J. Bacteriol. 2011, 193, 1930-1942. doi:10.1128/JB.01091-10

55. Berleman, J. E.; Chumley, T.; Cheung, P.; Kirby, J. R. J. Bacteriol. 2006, 188, 5888-5895. doi:10.1128/JB.00559-06

56. Wenzel, S. C.; Müller, R. Nat. Prod. Rep. 2009, 26, 1385-1407. doi:10.1039/b817073h

57. Cortina, N. S.; Krug, D.; Plaza, A.; Revermann, O.; Müller, R. Angew. Chem., Int. Ed. 2012, 51, 811-816. doi:10.1002/anie.201106305

58. Kunze, B.; Bedorf, N.; Kohl, W.; Höfle, G.; Reichenbach, H. J. Antibiot. 1989, 42, 14-17. doi:10.7164/antibiotics.42.14

59. Silakowski, B.; Kunze, B.; Nordsiek, G.; Blöcker, H.; Höfle, G.; Müller, R. Eur. J. Biochem. 2000, 267, 6476-6485. doi:10.1046/j.1432-1327.2000.01740.x

60. Schieferdecker, S.; König, S.; Koeberle, A.; Dahse, H.-M.; Werz, O.; Nett, M. J. Nat. Prod. 2015, 78, 335-338. doi:10.1021/np500909b

61. Wenzel, S. C.; Meiser, P.; Binz, T. M.; Mahmud, T.; Müller, R. Angew. Chem., Int. Ed. 2006, 45, 2296-2301. doi:10.1002/anie.200503737

62. Ohlendorf, B.; Kehraus, S.; König, G. M. J. Nat. Prod. 2008, 71, 1708-1713. doi:10.1021/np800319v

63. Meiser, P.; Bode, H. B.; Müller, R. Proc. Natl. Acad. Sci. U. S. A. 2006, 103, 19128-19133. doi:10.1073/pnas.0606039103

64. Meiser, P.; Weissman, K. J.; Bode, H. B.; Krug, D.; Dickschat, J. S.; Sandmann, A.; Müller, R. Chem. Biol. 2008, 15, 771-781. doi:10.1016/j.chembiol.2008.06.005

65. Krug, D.; Zurek, G.; Revermann, O.; Vos, M.; Velicer, G. J.; Müller, R. Appl. Environ. Microbiol. 2008, 74, 3058-3068. doi:10.1128/AEM.02863-07

66. Trowitzsch-Kienast, W.; Gerth, K.; Wray, V.; Reichenbach, H.; Höfle, G. Liebigs Ann. Chem. 1993, 1233-1237. doi:10.1002/jlac.1993199301200

67. Wenzel, S. C.; Kunze, B.; Höfle, G.; Silakowski, B.; Scharfe, M.; Blöcker, H.; Müller, R. ChemBioChem 2005, 6, 375-385. doi:10.1002/cbic.200400282
68. Miyanaga, S.; Sakurai, H.; Saiki, I.; Onaka, H.; Igarashi, Y. Bioorg. Med. Chem. 2009, 17, 2724-2732. doi:10.1016/j.bmc.2009.02.040

69. Korp, J.; König, S.; Schieferdecker, S.; Dahse, H.-M.; König, G. M.; Werz, O.; Nett, M. ChemBioChem 2015, 16, 2445-2450. doi:10.1002/cbic.201500446

70. Jansen, R.; Reifenstahl, G.; Gerth, K.; Reichenbach, H.; Höfle, G. Liebigs Ann. Chem. 1983, 1081-1095. doi:10.1002/jlac.198319830702

71. Gerth, K.; Jansen, R.; Reifenstahl, G.; Höfle, G.; Irschik, H.; Kunze, B.; Reichenbach, H.; Thierbach, G. J. Antibiot. 1983, 36, 1150-1156. doi:10.7164/antibiotics.36.1150

72. Friedrich, T.; Van Heek, P.; Leif, H.; Ohnishi, T.; Forche, E.; Kunze, B.; Jansen, R.; Trowitzsch-Kienast, W.; Höfle, G.; Reichenbach, H.; Weiss, H. Eur. J. Biochem. 1994, 219, 691-698. doi:10.1111/j.1432-1033.1994.tb19985.x

73. Bode, H. B.; Meiser, P.; Klefisch, T.; Cortina, N. S. D. J.; Krug, D.; Göhring, A.; Schwär, G.; Mahmud, T.; Elnakady, Y. A.; Müller, R. ChemBioChem 2007, 8, 2139-2144. doi:10.1002/cbic.200700401

74. Rosenberg, E.; Vaks, B.; Zuckerberg, A. Antimicrob. Agents Chemother. 1973, 4, 507-513. doi:10.1128/AAC.4.5.507

75. Gerth, K.; Irschik, H.; Reichenbach, H.; Trowitzsch, W. J. Antibiot. 1982, 35, 1454-1459. doi:10.7164/antibiotics.35.1454

76. Trowitzsch, W.; Wray, V.; Gerth, K.; Höfle, G. J. Chem. Soc., Chem. Commun. 1982, 1340-1342. doi:10.1039/C39820001340

77. Onishi, N.; Izaki, K.; Takahashi, H. J. Antibiot. 1984, 37, 13-19. doi:10.7164/antibiotics.37.13

78. Takayama, S.; Yamanaka, S.; Miyashiro, S.; Yokokawa, Y.; Shibai, H. J. Antibiot. 1988, 41, 429-445. doi:10.7164/antibiotics.41.439

79. Simunovic, V.; Zapp, J.; Rachid, S.; Krug, D.; Meiser, P.; Müller, R. ChemBioChem 2006, 7, 1206-1220. doi:10.1002/cbic.200600075

80. Rosenberg, E.; Dworkin, M. J. Ind. Microbiol. 1996, 17, 424-431. doi:10.1007/BF01574773

81. Xiao, Y.; Gerth, K.; Müller, R.; Wall, D. Antimicrob. Agents Chemother. 2012, 56, 2014-2021. doi:10.1128/AAC.06148-11

82. Xiao, Y.; Wei, X.; Ebright, R.; Wall, D. J. Bacteriol. 2011, 193, 4626-4633. doi:10.1128/JB.05052-11

83. Morett, E.; Segovia, L. J. Bacteriol. 1993, 175, 6067-6074.

84. Volz, C.; Kegler, C.; Müller, R. Chem. Biol. 2012, 19, 1447-1459. doi:10.1016/j.chembiol.2012.09.010

85. Bretscher, A. P.; Kaiser, D. J. Bacteriol. 1978, 133, 763-768.

86. Weissman, K. J.; Müller, R. Nat. Prod. Rep. 2010, 27, 1276-1295. doi:10.1039/c001260m

87. Schieferdecker, S.; König, S.; Weigel, C.; Dahse, H.-M.; Werz, O.; Nett, M. Chem. - Eur. J. 2014, 20, 15933-15940. doi:10.1002/chem.201404291

88. Zhang, L.; Wang, H.; Fang, X.; Stackebrandt, E.; Ding, Y. J. Microbiol. Methods 2003, 54, 21-27. doi:10.1016/S0167-7012(02)00257-9

89. Schieferdecker, S.; Exner, T. E.; Gross, H.; Roth, M.; Nett, M. J. Antibiot. 2014, 67, 519-525. doi:10.1038/ja.2014.31

90. Mohr, K. I.; Stechling, M.; Wink, J.; Wilharm, E.; Stadler, M. MicrobiologyOpen 2016. doi:10.1002/mbo3.325

91. Dawid, W. FEMS Microbiol. Rev. 2000, 24, 403-427. doi:10.1111/j.1574-6976.2000.tb00548.x

92. Surup, F.; Viehrig, K.; Mohr, K. I.; Herrmann, J.; Jansen, R.; Müller, R. Angew. Chem., Int. Ed. 2014, 53, 13588-13591. doi:10.1002/anie.201406973 
93. Hille-Rehfeld, A. Chem. Unserer Zeit 2015, 49, 90-91. doi:10.1002/ciuz.201580017

94. Holzgrabe, U. Pharmakon 2015, 3, 181-183.

95. Irschik, H.; Gerth, K.; Höfle, G.; Kohl, W.; Reichenbach, H. J. Antibiot. 1983, 36, 1651-1658. doi:10.7164/antibiotics.36.1651

96. Kohl, W.; Irschik, H.; Reichenbach, H.; Höfle, G. Liebigs Ann. Chem. 1983, 1656-1667. doi:10.1002/jlac.198319831003

97. Irschik, H.; Jansen, R.; Höfle, G.; Gerth, K.; Reichenbach, H. J. Antibiot. 1985, 38, 145-152. doi:10.7164/antibiotics.38.145

98. Jansen, R.; Höfle, G.; Irschik, H.; Reichenbach, H. Liebigs Ann. Chem. 1985, 822-836. doi:10.1002/jlac.198519850418

99. Schäberle, T. F.; Schmitz, A.; Zocher, G.; Schiefer, A.; Kehraus, S.; Neu, E.; Roth, M.; Vassylyev, D. G.; Stehle, T.; Bierbaum, G.; Hoerauf, A.; Pfarr, K.; König, G. M. J. Nat. Prod. 2015, 78, 2505-2509. doi:10.1021/acs.jnatprod.5b00175

100.Erol, Ö.; Schäberle, T. F.; Schmitz, A.; Rachid, S.; Gurgui, C.; El Omari, M.; Lohr, F.; Kehraus, S.; Piel, J.; Müller, R.; König, G. M. ChemBioChem 2010, 11, 1253-1265. doi:10.1002/cbic.201000085

101.Sucipto, H.; Wenzel, S. C.; Müller, R. ChemBioChem 2013, 14, 1581-1589. doi:10.1002/cbic.201300289

102.Schäberle, T. F. Beilstein J. Org. Chem. 2016, 12, 571-588. doi:10.3762/bjoc. 12.56

103.Schäberle, T. F.; Schiefer, A.; Schmitz, A.; König, G. M.; Hoerauf, A.; Pfarr, K. Int. J. Med. Microbiol. 2014, 304, 72-78. doi:10.1016/j.ijmm.2013.08.010

104.Mukhopadhyay, J.; Das, K.; Ismail, S.; Koppstein, D.; Jang, M.; Hudson, B.; Sarafianos, S.; Tuske, S.; Patel, J.; Jansen, R.; Irschik, H.; Arnold, E.; Ebright, R. H. Cell 2008, 135, 295-307. doi:10.1016/j.cell.2008.09.033

105.Srivastava, A.; Talaue, M.; Liu, S.; Degen, D.; Ebright, R. Y.; Sineva, E.; Chakraborty, A.; Druzhinin, S. Y.; Chatterjee, S.; Mukhopadhyay, J.; Ebright, Y. W.; Zozula, A.; Shen, J.; Sengupta, S.; Niedfeldt, R. R.; Xin, C.; Kaneko, T.; Irschik, H.; Jansen, R.; Donadio, S.; Connell, N.; Ebright, R. H. Curr. Opin. Microbiol. 2011, 14, 532-543. doi:10.1016/j.mib.2011.07.030

106. Cramer, P. Curr. Opin. Struct. Biol. 2002, 12, 89-97. doi:10.1016/S0959-440X(02)00294-4

107. Yamaguchi, H.; Nakayama, Y.; Takeda, K.; Tawara, K.; Maeda, K.; Takeuchi, T.; Umezawa, H. J. Antibiot. 1957, 10, 195-200.

108.Kunze, B.; Reichenbach, H.; Augustiniak, H.; Höfle, G. J. Antibiot. 1982, 35, 635-636. doi:10.7164/antibiotics.35.635

109. Fujimoto, H.; Kinoshita, T.; Suzuki, H.; Umezawa, H. J. Antibiot. 1970, 23, 271-275. doi:10.7164/antibiotics.23.271

110.Pestka, S. Althiomycin. In Mechanism of Action of Antimicrobial and Antitumor Agents; Corcoran, J. W.; Hahn, F. E., Eds.; Springer: Berlin, Heidelberg, New York, 1975; pp 323-326. doi:10.1007/978-3-642-46304-4_21

111.Cortina, N. S.; Revermann, O.; Krug, D.; Müller, R. ChemBioChem 2011, 12, 1411-1416. doi:10.1002/cbic.201100154

112.Gerc, A. J.; Song, L.; Challis, G. L.; Stanley-Wall, N. R.; Coulthurst, S. J. PLoS One 2012, 7, e44673. doi:10.1371/journal.pone.0044673

113.Baumann, S.; Herrmann, J.; Raju, R.; Steinmetz, H.; Mohr, K. I.; Hüttel, S.; Harmrolfs, K.; Stadler, M.; Müller, R. Angew. Chem., Int. Ed. 2014, 53, 14605-14609 doi:10.1002/anie.201409964
114. Garrity, G. M.; Holt, J. G.; Castenholtz, R. W.; Pierson, B. K.; Keppen, O. I.; Gorlenko, V. M. Phylum BVI. Chloroflexi phy. nov. In Bergey's Manual of Systematic Bacteriology, 2nd ed.; Garrity, G. M.; Boone, D. R.; Castenholz, R. W., Eds.; Springer: New York, 2001; Vol. 1, pp 427-446. doi:10.1007/978-0-387-21609-6_23

115. Hugenholtz, P.; Stackebrandt, E. Int. J. Syst. Evol. Microbiol. 2004, 54, 2049-2051. doi:10.1099/ijs.0.03028-0

116. Gupta, R. S.; Chander, P.; George, S. Antonie van Leeuwenhoek 2013, 103, 99-119. doi:10.1007/s10482-012-9790-3

117.Sutcliffe, I. C. Trends Microbiol. 2010, 18, 464-470. doi:10.1016/j.tim.2010.06.005

118. Frigaard, N.-U.; Bryant, D. A. Arch. Microbiol. 2004, 182, 265-276. doi:10.1007/s00203-004-0718-9

119.Lee, N.; Reichenbach, H. The genus Herpetosiphon. In The Prokaryotes, 3rd ed.; Dworkin, M.; Falkow, S.; Rosenberg, E.; Schleifer, K.-H.; Stackebrandt, E., Eds.; Springer: New York, 2006; Vol. 7, pp 854-877. doi:10.1007/0-387-30747-8_36

120.Ward, L. M.; Hemp, J.; Pace, L. A.; Fischer, W. W. Genome Announc. 2015, 3, e01352-15.

121. Kastner, S.; Müller, S.; Natesan, L.; König, G. M.; Guthke, R.; Nett, M. Arch. Microbiol. 2012, 194, 557-566. doi:10.1007/s00203-012-0789-y

122.Tang, K.-H.; Barry, K.; Chertkov, O.; Dalin, E.; Han, C. S.; Hauser, L. J.; Honchak, B. M.; Karbach, L. E.; Land, M. L.; Lapidus, A.; Larimer, F. W.; Mikhailova, N.; Pitluck, S.; Pierson, B. K.; Blankenship, R. E. BMC Genomics 2011, 12, No. 334. doi:10.1186/1471-2164-12-334

123. Nett, M.; Ikeda, H.; Moore, B. S. Nat. Prod. Rep. 2009, 26 , 1362-1384. doi:10.1039/b817069j

124.Rudolf, J. D.; Yan, X.; Shen, B. J. Ind. Microbiol. Biotechnol. 2016, 43, 261-276. doi:10.1007/s10295-015-1671-0

125.Nett, M.; Erol, Ö.; Kehraus, S.; Köck, M.; Krick, A.; Eguereva, E.; Neu, E.; König, G. M. Angew. Chem., Int. Ed. 2006, 45, 3863-3867. doi:10.1002/anie.200504525

126.Zhang, J.; Polishchuk, E. A.; Chen, J.; Ciufolini, M. A. J. Org. Chem. 2009, 74, 9140-9151. doi:10.1021/jo9018705

127.Schieferdecker, S.; Domin, N.; Hoffmeier, C.; Bryant, D. A.; Roth, M.; Nett, M. Eur. J. Org. Chem. 2015, 3057-3062. doi:10.1002/ejoc.201500181

128. Nakano, C.; Oshima, M.; Kurashima, N.; Hoshino, T. ChemBioChem 2015, 16, 772-781. doi:10.1002/cbic.201402652

129.Pidot, S. J.; Coyne, S.; Kloss, F.; Hertweck, C. Int. J. Med. Microbiol. 2014, 304, 14-22. doi:10.1016/j.jmm.2013.08.011 


\section{License and Terms}

This is an Open Access article under the terms of the Creative Commons Attribution License

(http://creativecommons.org/licenses/by/2.0), which permits unrestricted use, distribution, and reproduction in any medium, provided the original work is properly cited.

The license is subject to the Beilstein Journal of Organic Chemistry terms and conditions:

(http://www.beilstein-journals.org/bjoc)

The definitive version of this article is the electronic one which can be found at:

doi:10.3762/bjoc. 12.58 